\title{
VEGETATION AND CLIMATIC CHANGES IN THE MERIDA ANDES DURING THE LAST 13,000 YEARS
}

\author{
M.L.Salgado-Labouriau ${ }^{1}$
}

This article presents a comparison of the paleoecological results from the Mérida Andes, in Venezuela, including different elevations and different mountain ranges. No attempt is done to correlate it with the results from other Andean mountains, although it certainly exists. The purpose here is to organize and compare the data from seven stratigraphic sections (Table I) at elevations above $3,000 \mathrm{~m}$ from the Mérida Andes in order to identify changes in vegetation and climate in the last 13,000 years.

Deglaciation started at 12,650 B.P. in elevations of $3,500-3,600 \mathrm{~m}$ and plants began to colonize the deglaciated soil (SALGADO-LABOURIAU et al., 1977). At about 8,300-7,530 B.P. the Mucubají glacial valley and the Páramo de La Culata were covered already by a rich páramo vegetation. At 3,900 m elevation (Páramo de Miranda) colonization occurred much later (ca. 9,400 B.P.) showing a delay according to elevation, as one might expect. The sequence of arrival of each pollen type was the same in Mucubaji and in Miranda. Figure 1 depicts the arrival of the páramo elements at the superpáramo (elevations above 3,900 m). Colonization took place slowly after the glacial cirque of Miranda was deglaciated.

The almost continuous record for more than $11,470+170$ radiocarbon years B.P. to present (SALGADO-LABOURIAU et al., 1988) show that the diversity of pollen and spores assemblages of páramo elements increased due to new arrivals until about 3,000 B.P. (Fig. 1). From there onwards these assemblages contained all the elements found in modern deposition inside the cirque. These results (SALGADO-LABOURIAU, 1988) illustrate how long it takes to form a superpáramo vegetation after its destruction.

The paleoecological results from the six sites were summarized on Table II. It represents a tentative interpretation of the climatic oscillations and vegetational changes during the last 13,000 years.

\footnotetext{
$T_{\text {Instituto de Geociências, Universidade }}$ de Brasília, 70910 - Brasília, DF, Brazil.
} 


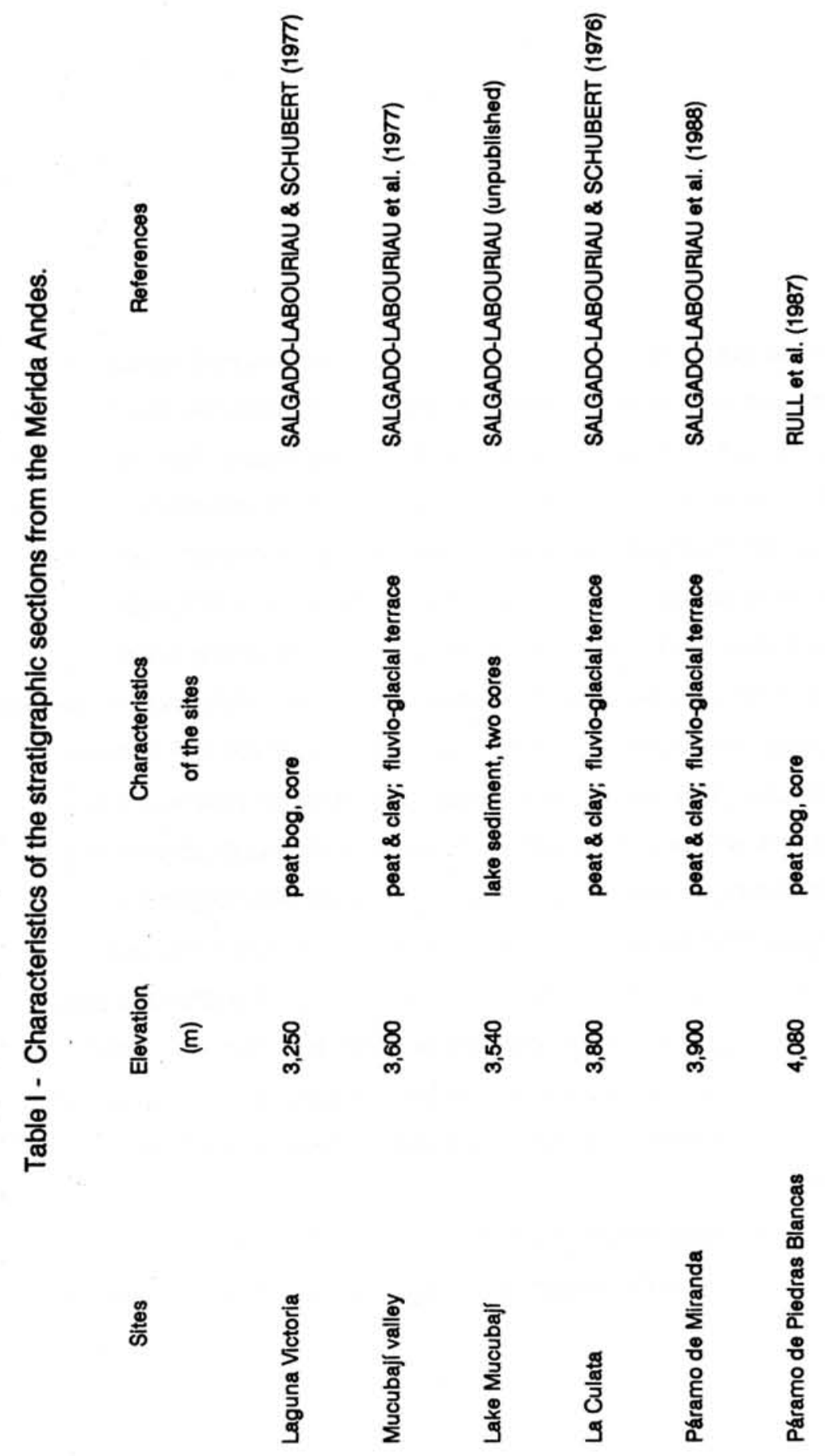


plantago

$\frac{\text { JAMESONIA }}{\text { ORABA }}$
ISOETES
HYPOCHOERIS AND
OUHER FENESIRAIE
RHIZOCEPHALUM
GERANIUM
ESPELETIA SCHULTZII
OXYLOBUS BLAKIELLA
INULEAE

PSILATE MONOLETE SPORE

VALERIANA

LYCOPODIUM

SENECIO

HELIANTHEAE (others)

ARENARIA

ARENARIA
CERASTIUM
CONYZA SUBTYPE
LAGENOPHORA SUBTYPE
BACCHARIS SUBTYPE
COESPELETIA SPICATA
COESPELETIA
MORITZIANA-TIMOTENSIS
GENTIANA
CYPERACEAE
MONTIA

GRAMINEAE

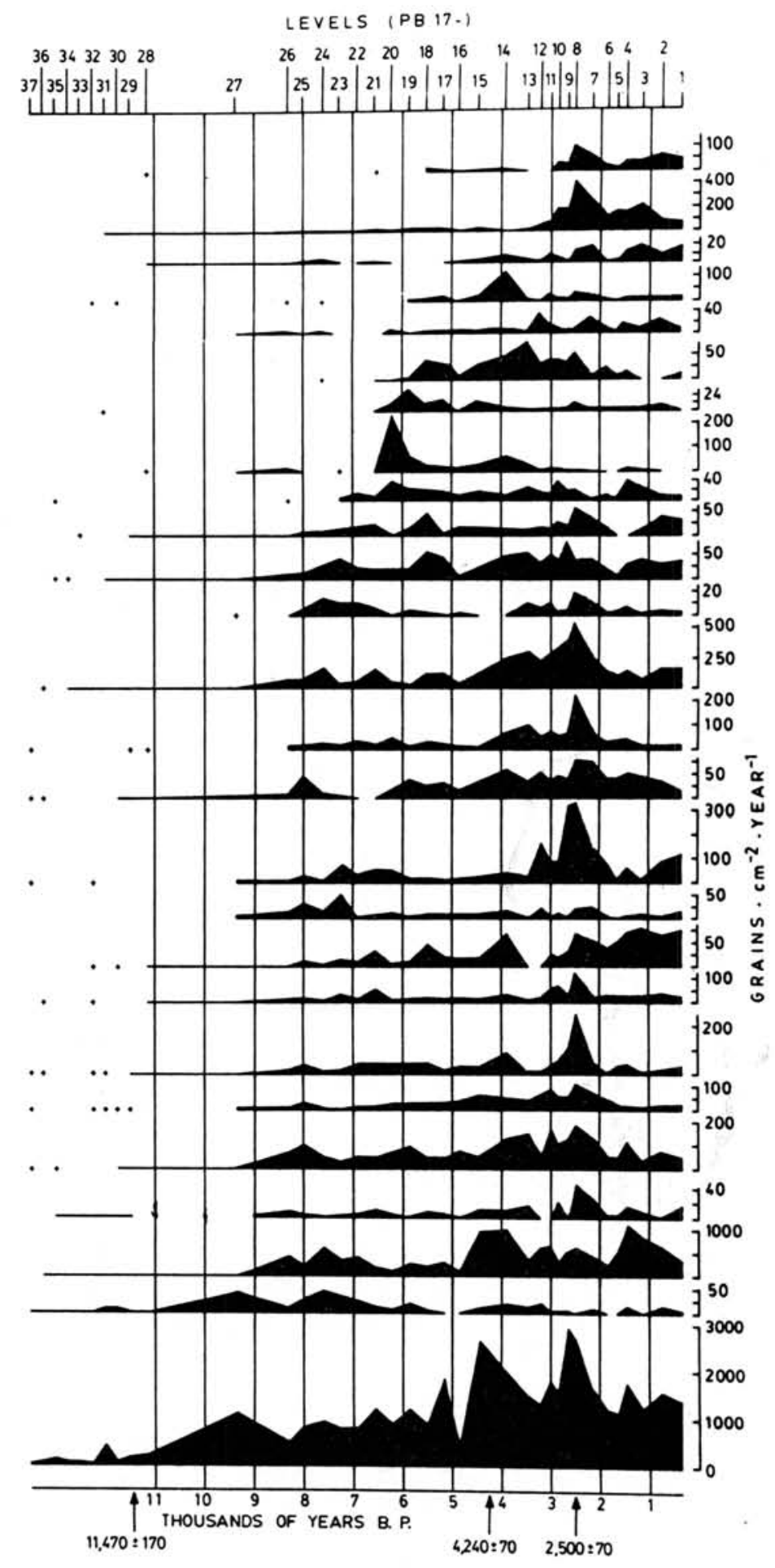

Figure 1 - Sequence of arrival of paramo pollen and spores at the Miranda glacial cirque after deglaciation. The asterisks at the left of the curves indicate a low frequence isolated occurrence; the first peak is considered to be the time when the taxon started to grow around the site (after SALGADO-LABOURIAU, 1988). 


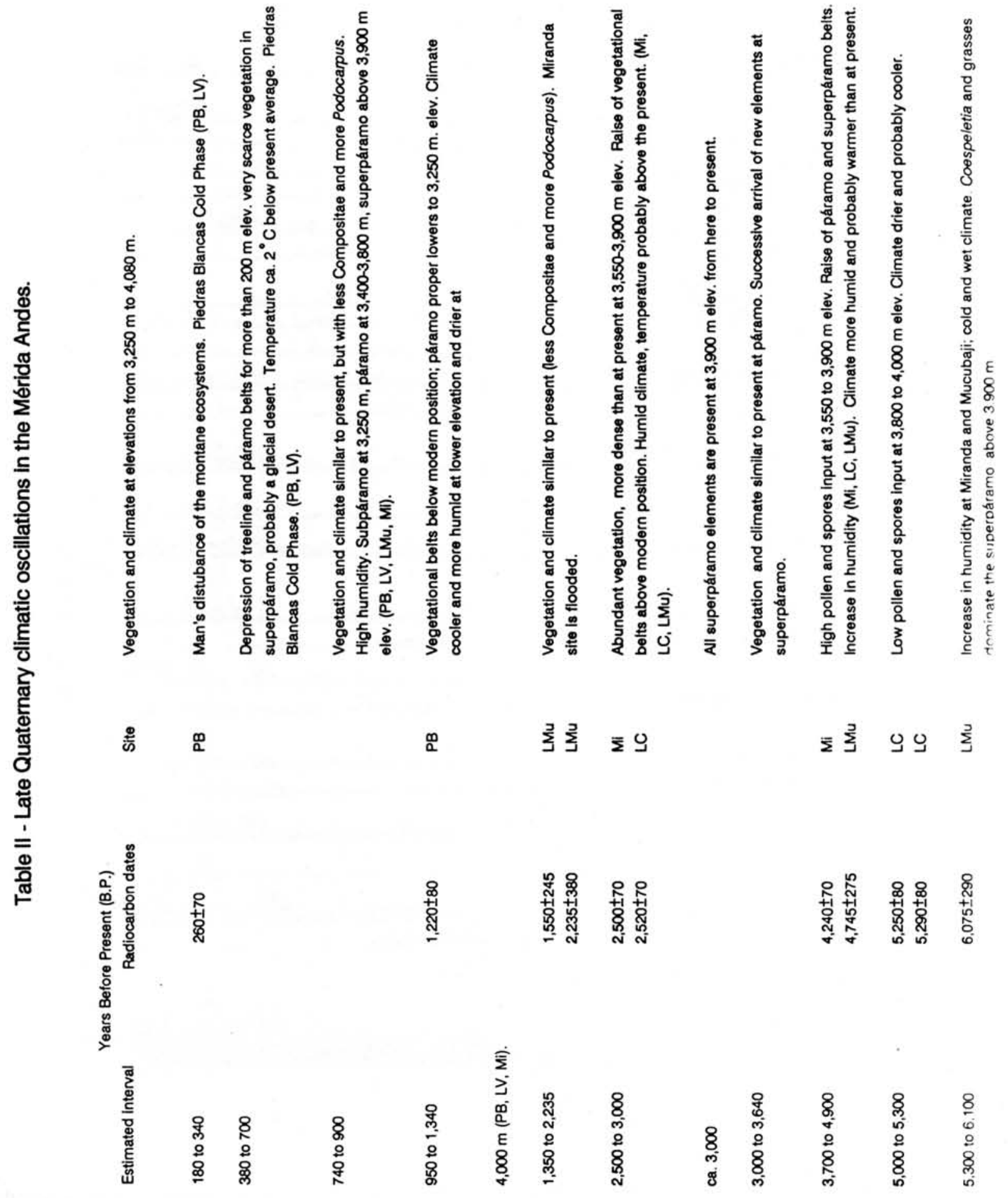




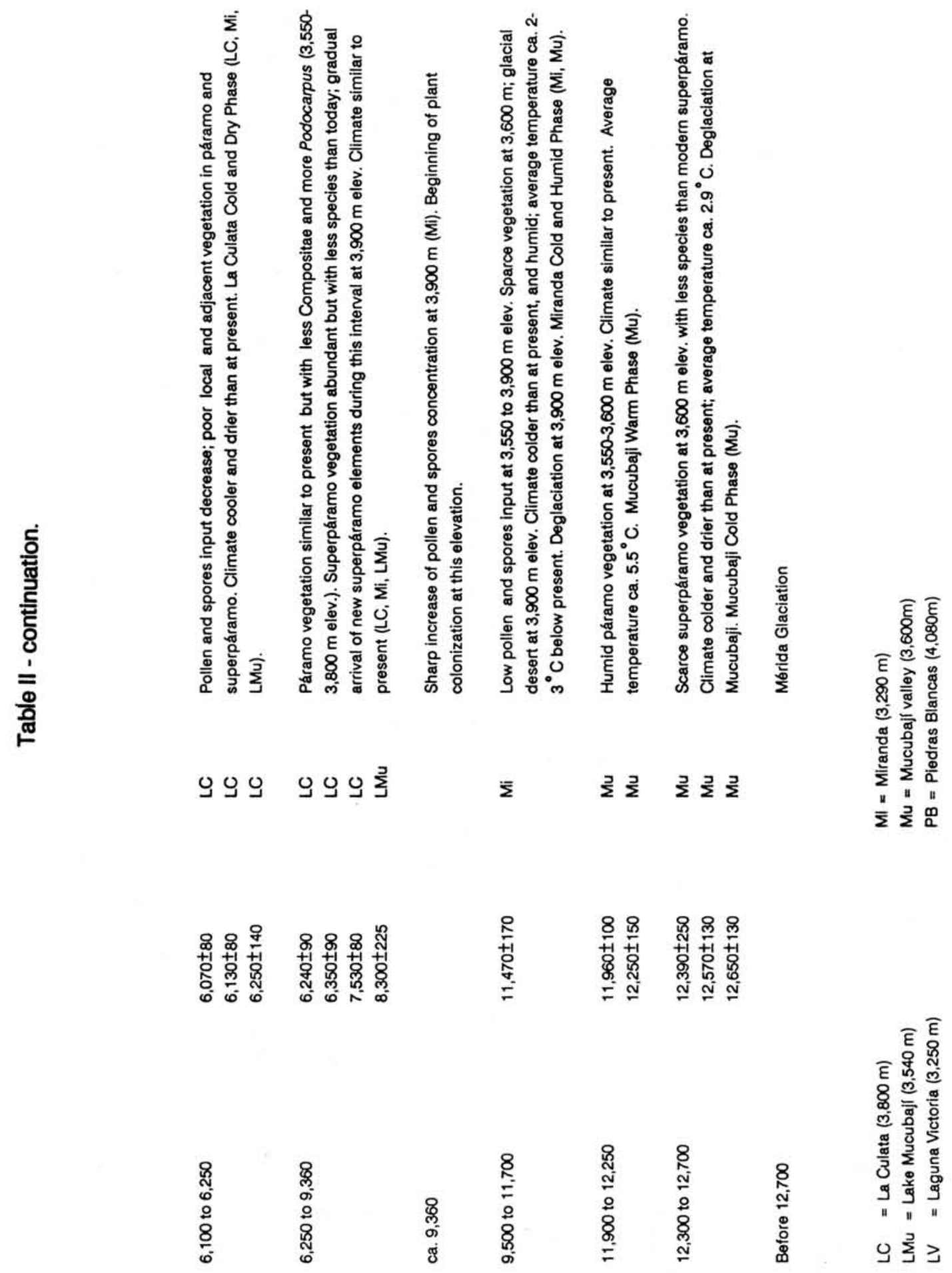


The comparison of the different sites showed that it was possible to ascertain the same oscillations of temperatures in the different sites because the events were marked in the pollen assemblages being thus, simultaneous. Five cold phases were detected, respectively at: ca. 700-100 B.P.; ca. 940-1,340 B.P.; ca. 5,300-6,250 B.P.; 9,500-11,700 B.P. and, ca. 12,300-12,700 B.P. In these phases the temperature was below the modern average. Two warm phases had temperature above the present (ca. 2,500 to 3,000; and probably at ca. $3,700-4,900$ B.P.). The rest of the time was similar to the present temperature.

In contrast, the degree of humidity varied from site to site and only rarely its change was synchronous in two different elevations. The strongest difference between sites occurred at the time interval of 940-1,340 B.P. when the higher elevations were drier than at present, whereas Laguna Victoria at 3,250 m, today at the páramo-forest ecotone, was larger than at present and its waters covered the core site which at present is a peat bog close to it.

These results indicate that changes in humidity were local events whereas changes in temperature were simultaneous and involved the whole mountain system of Mérida. They also show that a decrease in temperature (below modern average) is not always connected with dryness. There were cold phases that were relatively dry and others that were relatively wet, such as, respectively, at $12,300-12,700$ B.P. and at 9,500-11,700 B.P. (Table II).

The comparison among the pollen and spores diagrams from different sites in the Andes of Mérida has shown that the composition of vegetation was not the same during the Late Quaternary. It had less species after deglaciation and increased slowly in number of species, as described above. Furthermore, dominance of páramo elements and of arboreal pollen changed in the last centuries indicating disturbance of the natural environment.

Archeological data from the Venezuelan Andes have shown that there were no permanent settlements at elevations above 3,000 $\mathrm{m}$ before the arrival of the Europeans. The pre-colombian inhabitants lived below the páramos, and visited the highlands occasionally for short periods of time. They had no type of livestock, but agriculture was present up to 3,000 m elevation, and especially between 2,000 and $800 \mathrm{~m}$ (WAGNER, 1967, 1979). They probably never had a dense population in the Andes. Shortly after the Spanish arrival, in 1570 A.D. European cattle was introduced in the Andes (FEBRES, 1930) and it was raised up to $4,000 \mathrm{~m}$ elevation. Intense agriculture began at this time resulting in the almost destruction of the lower belt of montane forest that limits with the savannas of the Lanos. The cloud forest at 1,700 to 3,300 $\mathrm{m}$ elevation was deforested in the plateaux but the steep slopes still have primary forest. During the last hundred years, coffee has been cultivated in the lower slopes, and potato and wheat in the transition zone between páramo and montane forest. At present other plants were added and the terraces are intensely cultivated. Many exotic trees, such as Pinus and Eucalyptus were introduced above the present tree line and in the páramo-forest ecotone.

The disturbance of the natural montane ecosystems is marked in the pollen assemblages 
of the upper layers of sediments, a few centimeters from the top. This is clearly seen in three families, the Podocarpaceae, the Gramineae and the Compositae.

\section{PODOCARPACEAE}

Podocarpus is a genus of coniferous trees and shrubs of the southern hemisphere, western China and Japan. The Venezuelan species are trees of the montane rainforest that may reach $45 \mathrm{~m}$ height (VEILLON, 1962). The most common species in the Andean cloud forest is Podocarpus rospighiosii Pilger (Decussocarpus rospighiosii (Pilger) De Laubenfels). Many modern species of the genus Podocarpus I'Heritier ex Person have been recently grouped into two new genera by DE LAUBENFELS (1982) but for the purpose of this article we will use Podocarpus sensu l'Heritier including the three genera of De Laubenfels. The study of the pollen morphology of the South America species is greatly needed to allow their identification in sediments, at the species level.

Pollen of Podocarpus is transported by wind up to the regions above the tree line. The number of grains decreases gradually with elevation thus allowing a rough estimation of the distance between the deposition site and the elevation where the trees grow (SALGADO-LABOURIAU, 1979). The pollen analyses of sediments above the tree line from the Venezuelan Andes has shown that the frequency and concentration of Podocarpus pollen was much higher in the past. In all the stratigraphic levels where forest pollen is abundant its grains are the dominant or the co-dominant among the tree pollen. It is frequent at Piedras Blancas (levels 16 to 26), at Miranda (levels 7 to 26), at La Culata (all levels), at Lake Mucubaji and the Mucubaji terrace, and at Laguna Victoria (levels 9 to 18). Its maximum was reached around 900 B.P. Nevertheless, in the few centimeters below the surface, and in the modern deposition of pollen, its frequency is low suggesting that these trees were much more abundant in the past.

The deposition of pollen and spores from the cloud and the gallery forest elements diminished from about 700 B.P. onwards showing a retreat of the forest belt towards low elevations. This marks the beginning of the Little lce Age in the Mérida Andes (RUL et al., 1987). Although Podocarpus pollen follow this decrease, it further reduces or disappears from 340 B.P. (17th century) onwards, loosing its dominance over the arboreal pollen and suggesting that the trees were cut down after the Spanish arrival at the Venezuelan Andes.

Podocarpus wood can be used for the same purposes of pine wood. Its trees were probably cut down for this purpose shortly after the beginning of the Spanish settlement in the Mérida Andes. Large trees are still abundant in steep slopes and in some forest reservations such as "La Carbonera". Sometimes single trees are found growing in pastures as a remnant of the former forest. 


\section{GRAMINEAE}

Grass pollen is the dominant over all the pollen types in the old sediment pollen assemblages above $3,250 \mathrm{~m}$ elevation from 13,000 years B.P. onwards. Nevertheless, it is not dominant in the samples of modern deposition. Its decline at present is usually limited to the uppermost levels, a few centimeters from the soil suface, where it decreases to modern values for the site. An example of this decline is illustrated in the pollen diagram of Piedras Blancas (Fig. 2) and in the modern pollen deposition from Miranda (top of Fig. 3). Radiocarbon date of the Piedras Blancas section show that it occurred after $250 \pm 70$ B.P., thus indicating that the decline took place in the last centuries. At present the soil is covered by grasses in the páramo grassland,in the shrub páramo and in the transition zone between páramo and forest. They are much more abundant than any herb. At the superpáramo the grass cover is scarce and the rocky soil is mostly bare. This field observation suggests that grass pollen is under-represented in modern assemblages of páramo.

Because no other element shows this change in representation, and grasses are high pollen producers, one may infer that a new factor came into play in the last two centuries. Archeological evidence indicates that the páramo never had a dense human population in Venezuela prior to the Spanish arrival. Lamas, vicuñas and other camelidians did not live in the Venezuelan mountains (WAGNER, 1967, 1979). Historical documents give 1,570 A.D. for the introduction of European cattle there and the beginning of agriculture (FEBRES, 1930).

Today husbandry is done up to almost $4,000 \mathrm{~m}$ elevation and is intense in many places. Based on the pollen analyses it can be assumed that after the $17^{\text {th }}$ century cattle grazing was sufficiently intensive to prevent flowering of the grasses. Therefore, although they exist and constitute the dominant plants of the low stratum, their pollen production is low.

\section{COMPOSITAE}

At present Compositae plants are abundant up to the snow line (approx. 4,700 $\mathrm{m}$ elevation). The genus Espeletia is the most common from 2,800 to 3,800 m. E. schultzii forms pure stands in some páramo and covers the old moraines in places as the Mucubaji valley. The tall rosette-forming plants of several species of the genus Coespeletia are mostly found above 3,800 m elevation. They grow side by side on rocky soil in large areas of the Páramo de Piedras Blancas at 3,900-4,400 m elevation.

Compositae pollen is the dominant or the co-dominant in the modern assemblages from surface soil indicating that it is well represented in the samples. Nevertheless, it is not frequent in the old pollen assemblages showing that the individual plants were not so abundant in the past. 


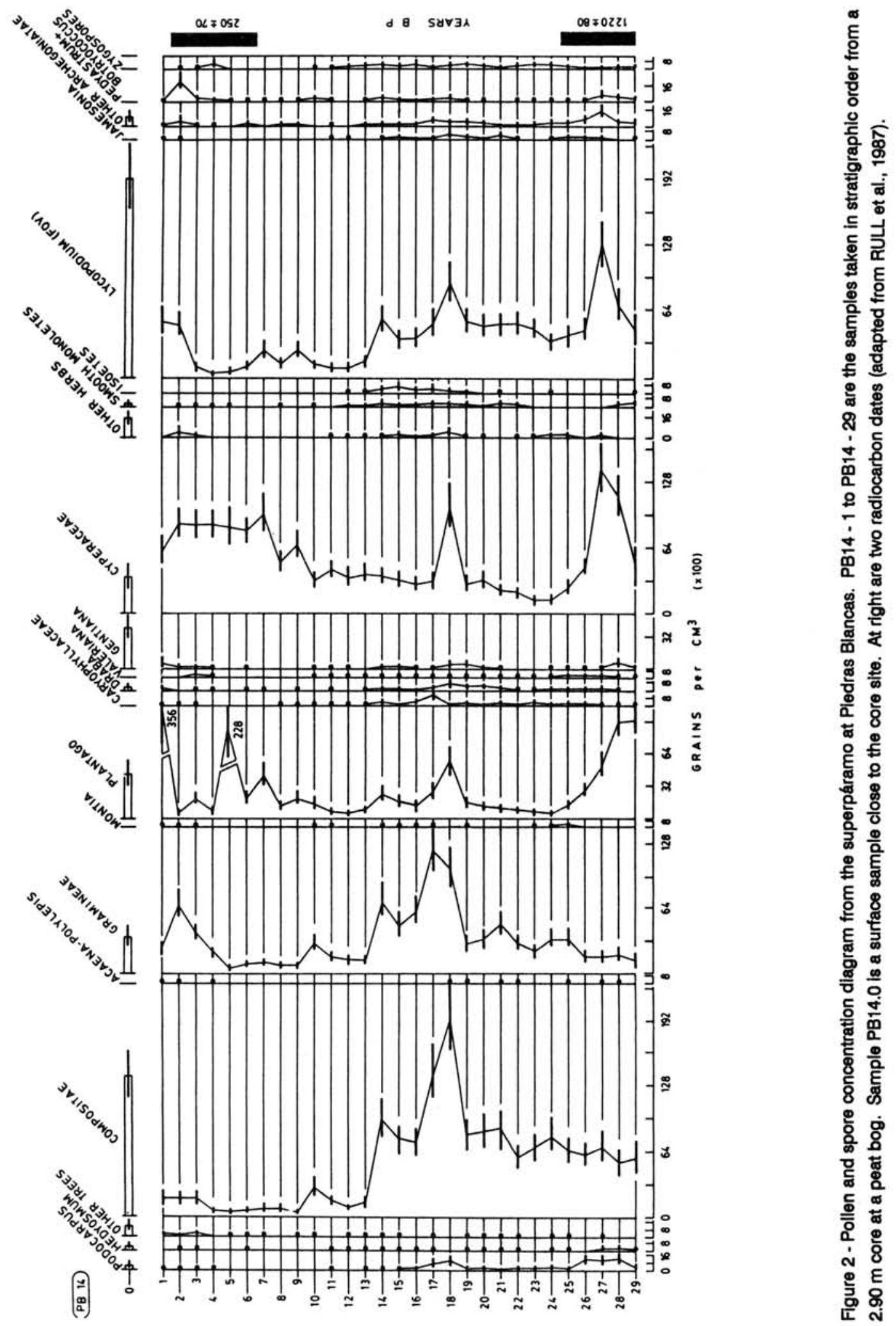




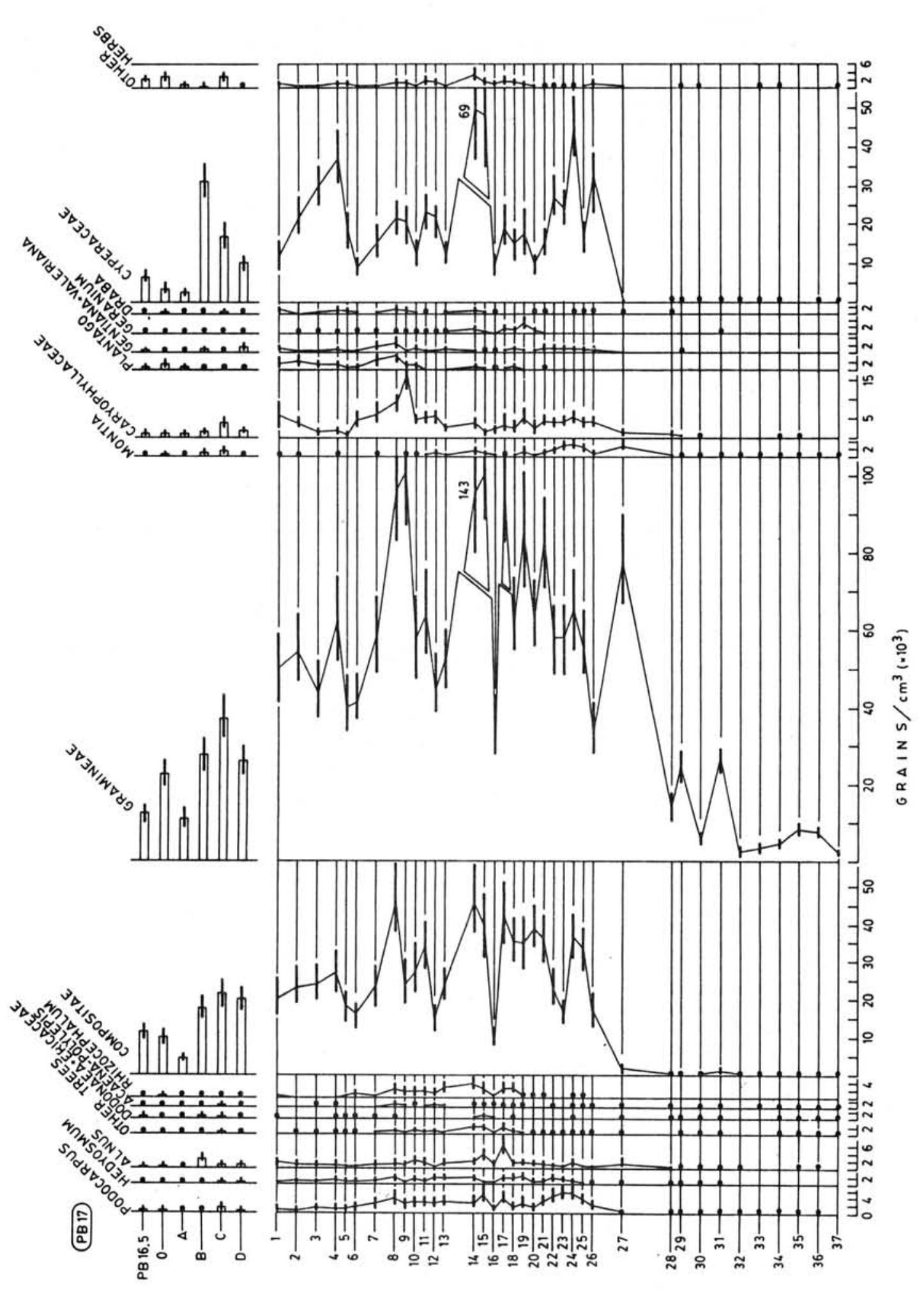

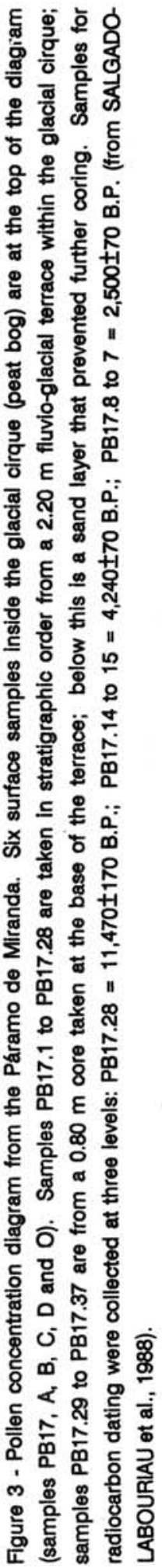


The increase of their pollen is at the same time as the grass pollen decline suggesting that it is related with the use of the land. Nevertheless, the role of man in the multiplication of Compositae plants is not clear. Espeletia schultzii is a invader of fallow lands at low elevations where forest was cut down for agriculture of pasture use (SALGADO-LABOURIAU, 1982). Nevertheless, its abundance in the páramo proper as well as the high frequency of three species of the genus Coespeletia in the superpáramo can not be explained by invasion of untilled land. Their recent expansion is still an open problem.

\section{ACKNOWLEDGEMENTS}

The author is grateful to Prof. Kenitiro Suguio for the opportunity to participate in the International Symposium on Global Changes. This study was partially supported by CONICIT (Venezuela), CNPq and FINEP (Brazil).

\section{REFERENCES}

BRADLEY, R.S.; YURETICH, R.F.; SALGADO-LABOURIAU, M.L; WEINGARTEN, B. (1985) Late Quaternary paleoenvironments from the Venezuelan Andes: preliminary results. Zeitschrift für Gletscherkunde, 21:97-106.

DE LAUBENFELS, D.J. (1982) Podocarpaceae. Flora de Venezuela, Caracas, 11(2):7-41.

FEBRES, C.T. (1930) Archivo de Historia y variedades. Caracas, Editorial León. V. 1, p.192-197.

RULL, V.; SALGADO-LABOURIAU, M.L; SCHUBERT, C.; VALASTRO JR., S. (1987) Late Holocene temperature depression in the Venezuelan Andes: palynological evidence. Palaeogeography, Palaeoclimatoogy, Palaeoecology, 60(1/2):109-121.

SALGADO-LABOURIAU, M.L (1979) Modern pollen deposition in the Venezuelan Andes. Grana, 18:53-68.

SALGADO-LABOURIAU, M.L (1982) Pollen morphology of the Compositae of the northern Andes. Pollen et Spores, 24(3-4):397-452.

SALGADO-LABOURIAU, M.L (1988) Sequence of colonization by plants in the Venezuelan Andes after the 
last Pleistocene glaciation. Journal Palynology, 23-24:189-204.

SALGADO-LABOURIAU, M.L. \& SCHUBERT, C. (1976) Palynology of Holocene peat bogs from the Central Venezuelan Andes. Palaeogeography, Palaeoclimatology, Palaeoecology, 19(2):147-156.

SALGADO-LABORIAU, M.L; SCHUBERT, C.; VALASTRO JR., S. (1977) Paleoecologic analysis of a Late Quaternary terrace from Mucubajl, Venezuelan Andes. Journal Biogeography, 4:313-325.

SALGADO-LABOURIAU, M.L; RUL, V.; SCHUBERT, C.; VALASTRO JR., S. (1988) The establishment of vegetation after the Late Pleistocene deglaciation in the Páramo de Miranda, Venezuelan Andes. Review Palaeobotany and Palynology, 55(1-3):5-17.

VEILLON, J.P. (1962) Coniferas autóctonas de Venezuela - Los Podocarpus. Mérida, Edición Universidad de Los Andes. 159p.

WAGNER, E. (1967) The pre-history and ethnohistory of the Carache area in the Western Venezuela. Yale University Publications in Anthropology, 71:1-107.

WAGNER, E. (1979) Arqueología de los Andes venezolanos. In: SALGADO-LABOURIAU, M.L. (ed.) EI Medio ambiente "Páramo". Caracas, Centro de Estudios Avanzados/IVIC. p.207-218. 